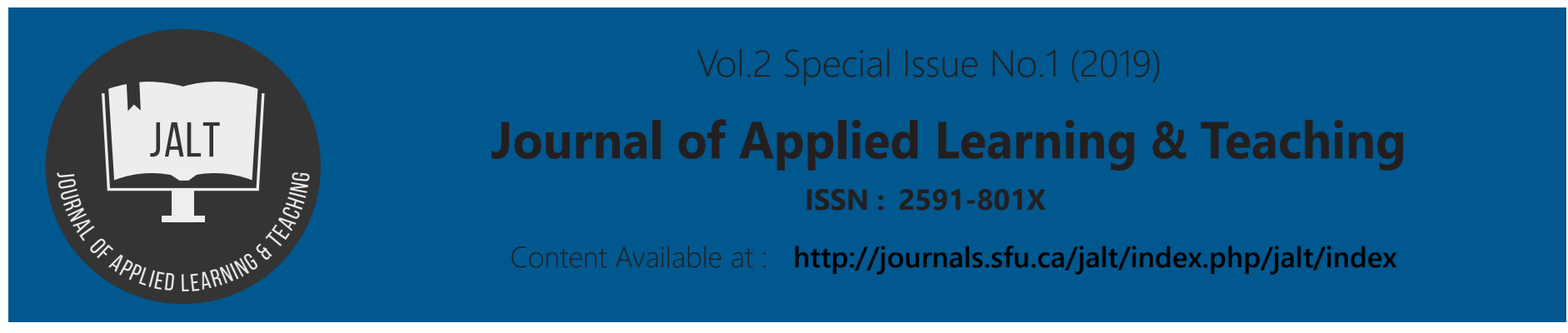

A new funding solution for curriculum development: Positioning a new approach from the SaaS industry to drive more curriculum content

\section{Alexander Ziegler}

\section{Keywords}

Crowdsourcing;

curriculum development;

funding;

SaaS.

\section{Article Info}

Received 17 May 2019

Received in revised form 18 July 2019

Accepted 25 July 2019

Available online 13 December 2019

DOI: https://doi.org/10.37074/jalt.2019.2.s1.6
Program Director, Education Business Development, IBM, Germany; Doctoral candidate, Edinburgh Napier University, Scotland

\section{Abstract}

Purpose: This paper is extending the existing body of knowledge by adding a new conceptual framework around funding of curriculum development for education in the SaaS (Software as a Service) industry.

Design/methodology/approach: This paper is investigating a new crowdsourcing curriculum development approach that is currently rolled out by one large SaaS vendor (IBM) to understand their solution. Based on literature research, the key properties of 'crowds' will be identified. The literature review is, in addition, giving an overview on how the new approach fits to existing knowledge.

Findings: The current research will differentiate the new approach from existing solutions in the literature and provide a suggestion for categories helping companies to understand the differences or similarities to other approaches.

Originality/Value: This study is building the conceptual framework of a model outlining multiple approaches for funding for curriculum development with the help of a crowd. 


\section{Introduction}

\section{Background}

The term 'crowd' is still showing increasing interest in Google (Google Trends: crowd, 2019). Google shows more than 16 million hits for the word 'crowdsourcing' in 2019. This is in line with Pisano (2015) who says companies need an innovation strategy, but many companies are still in the process of designing theirs. Looking into SaaS companies' data shows that, in general, they are driving innovation, but this does not mean every problem is already solved. IBM, as a large SaaS company, has been known for its innovation throughout its history (Chesbrough, 2007).

\section{Curriculum Development and SaaS}

Looking into the area of education, the digital transformation is still ongoing (Croft, 2018). People are focusing considerably on finding solutions for the talent gap (Leaser, 2015). However, there are other issues in the background of driving skills, especially in SaaS organisations: The innovation cycle, which is closer to six months in SaaS than three years, as in normal companies, is challenging education in SaaS: Curriculum Development needs to cope with the new rhythm.

The short innovation cycles are one of the root causes of increasing funding challenges in curriculum development. As users usually use the same release for 3-4 years compared to a release cycle of 6-12 months, this means one-third of the revenue and profit for each developed course. On the other hand, all software companies are facing more and more profit challenges. Last, but not least, there is the added consideration of ongoing consolidation (McKinsey \& Co., 2008).

\section{This paper}

This research contributes to the existing body of knowledge in two ways. Its first focus is to provide basic and intermediate new knowledge that can be re-used later on. Furthermore it will describe a new approach around funding curriculum development not yet covered in literature and position it in relationship to the properties of crowdsourcing other authors describe in existing academic literature. The investment into the detailed exploratory experience will add a second value. Other SaaS companies will be able to either expand on the experience or copy the approach.

\section{Outlook}

A suggestion for further research could be to investigate similar approaches that are combining crowdsourcing and funding as incentive. As the current research is using a relatively small crowd, the thinking of Peisl, Selen and Raeside (2014) could also lead to an additional research question to investigate whether increasing the crowd in this case could lead to better results.

\section{Literature Review}

\section{Crowdsourcing, Curriculum Development, Funding}

Running a library search for the word 'crowdsourcing' in the title resulted in more than 6,900 articles. Similarly, the word 'curriculum development' also obtained more than 6,100 hits. However, a combination of the two concepts to 'crowdsourcing curriculum', only resulted in four hits. There is no need to add the 'funding'. In detail, there are two results from peer reviewed journals (Paulin \& Haythornthwaite, 2016; White-Farnham \& Gardner, 2014), a conference paper (Zheng \& Dawson, 2017) and a general article (Lamb, 2016). Running a search in Google for 'crowdsourcing curriculum' results in more than 600,000 hits. The first statement suggests that the topic is a niche area. Combined with the high number of Google hits, this suggests that there has been much ongoing interest in this area during the last three years and an increase of the number of academic articles can be expected in the future.

The results from White-Farnham and Gardner (2014) and Paulin and Haythornthwaite (2016) suggest that curriculum created by 'crowds' is not only contributing to knowledge in general, but is also appreciated from a quality point of view (Paulin \& Haythornthwaite, 2016). There is also further research that highlights that there will be more usage of the crowd in the future (White-Farnham \& Gardner, 2014). Both also discuss the challenges around the motivation to attract the crowd.

All existing literature around curriculum and crowd has in common that the motivation is mentioned, but not discussed, as the used crowd is attracted based on self-motivation.

This also means there is no discussion around funding to motivate the crowd in existing literature.

\section{Properties of crowds: Size \& Motivation / Funding}

Using the existing literature around crowd but not talking about curriculum development gives the opportunity to investigate what is typical for a crowd. The key properties of a crowd are summarised below in Table 1.

\begin{tabular}{ll} 
Key properties of 'Crowds' & \\
\hline Property of crowd & Possible Values \\
\hline Size & Small, medium, large, 'relevant' \\
Motivation & $\begin{array}{l}\text { Enjoyment, fun, self-motivation, monetary } \\
\text { rewards }\end{array}$
\end{tabular}

Table 1: Key properties of 'Crowds' (Kozinets, Hemetsberger, \& Schau, 2008 Haag, Frey \& Lüthje, 2011).

In talking about the size, multiple authors mention large and organised groups as important. Which is interesting, as there is more research suggesting to use large and heterogenic crowds, for example, Rosenkopf and Nerkar (2001), and Lang, Bharadwaj, and Di (2016). But, on the other hand, there is the empirical research from Haag et al. (2011) who found only marginal evidence around the influence of heterogeneity or the size of the crowd around the outcome. 
Thus, this is questioning Kozinets et al. (2008) who mention size as a property in their crowd definition. It seems to be important to consider the finding of van Delden (2014), who stresses that you need to tap into the relevant crowd. Based on this, the current research is using a crowd that seems relevant in the context.

In terms of motivation, it is important to highlight that described monetary rewards are a one-time reward for a certain contribution. In all reviewed literature, the focus of the usage of the crowd is on innovation, thus, a onetime monetary reward is well-invested from an organisational point of view: the payment is made for an innovation that could have probably not been created inside the company.

\section{Crowdsourcing development and funding}

Moving down from strategy to process level, West and Gallagher (2006) look in general into how the crowd can help in the process side. Their work is scaffolded on open source development and, in the absence of literature around curriculum development together with the crowd, it seems to be a good fit to build on their experience, as shown in Table 2.

\begin{tabular}{llll}
\hline $\begin{array}{l}\text { Development } \\
\text { Strategy }\end{array}$ & $\begin{array}{l}\text { Maximising returns } \\
\text { of internal } \\
\text { innovation }\end{array}$ & $\begin{array}{l}\text { Role of external } \\
\text { innovation }\end{array}$ & $\begin{array}{l}\text { Motivation external } \\
\text { innovation }\end{array}$ \\
\hline $\begin{array}{l}\text { Pooled R\&D product } \\
\text { development }\end{array}$ & $\begin{array}{l}\text { Participants jointly } \\
\text { contribute to shared } \\
\text { effort }\end{array}$ & $\begin{array}{l}\text { Pooled contributions } \\
\text { available to all }\end{array}$ & $\begin{array}{l}\text { Ongoing institutions } \\
\text { establish legitimacy } \\
\text { and continuity }\end{array}$ \\
Spinouts & $\begin{array}{l}\text { Seed non- } \\
\text { commercial } \\
\text { technology to } \\
\text { support other goals }\end{array}$ & $\begin{array}{l}\text { Supplants internal } \\
\text { innovation as basis } \\
\text { of ongoing } \\
\text { innovation }\end{array}$ & $\begin{array}{l}\text { Free access to } \\
\text { valuable technology }\end{array}$ \\
Selling complements & $\begin{array}{l}\text { Target highest value } \\
\text { part of whole } \\
\text { product solution }\end{array}$ & $\begin{array}{l}\text { External components } \\
\text { provide basis for } \\
\text { internal development }\end{array}$ & $\begin{array}{l}\text { Firms coordinate } \\
\text { ongoing supply of } \\
\text { components }\end{array}$ \\
$\begin{array}{l}\text { Donated } \\
\text { complements }\end{array}$ & $\begin{array}{l}\text { Provide an } \\
\text { extensible platform } \\
\text { for external } \\
\text { contributors }\end{array}$ & $\begin{array}{l}\text { Adding variety and } \\
\text { novelty to } \\
\text { established products }\end{array}$ & $\begin{array}{l}\text { Recognition and } \\
\text { other non-monetary } \\
\text { rewards }\end{array}$ \\
\hline
\end{tabular}

Table 2: Open source strategies as solutions to open innovation challenges (West \& Gallagher, 2006).

It is important to highlight that West and Gallagher (2006) also explore the same question as the currently discussed research - how to motivate individuals and organisations to contribute to the crowd. They state that, without any incentive, neither organisations nor individuals will contribute in the long run.

They suggest the topic of this research paper as one of their open questions: What other options exist between 'relying on free spillovers and coordinating a complex production ecosystem.

\section{Research Methodology}

\section{Overview}

As the literature review pointed out, there is not a lot of literature overall on the topic of crowd and curriculum development, and none bringing this together with the topic of funding addressed in this research.

However, there are some sources talking about the categorisation of certain crowdsourcing properties, for example, West and Gallagher (2006).

Our methodology relies on the research by Christensen and Carlile (2009) who describe how theory building occurs in three stages. Yin (2009) states that the use of case studies can help when researchers want to look for answers to how or why things work in real life.

Therefore, theory generated from a specific case of a specific company may help future researchers to not only build upon phase three, as outlined by Christensen and Carlile (2009), but also help companies to build new ideas.

The author obtained access to the data based on his own professional role around business development in IBM. As a side challenge to his general work, he was tasked with finding a solution to source curriculum development taking into consideration the focus on SaaS in IBM and the very short product life cycles. As IBM is a part of TSIA (2019) the author received from TSIA the confirmation that software vendors today are either using non-controlled crowdsourcing or subcontracting. As neither approach fits the requirements, a new approach was, therefore, needed.

From an ethical point of view, the new approach may sound as if organisations are expanding more and more in using external resources instead of recruiting new workforce. However, it needs to be kept in mind that there are results from Huizingh (2011) which outline that, by expanding the workforce beyond the organisation's boundaries, the potential of innovation is increased.

\section{Overview of the new approach}

To solve the challenges of finding new ways to fund curriculum development, the author initiated a new approach in IBM to develop course materials for technical training for their products. Multiple conditions were the foundation of the decision.

The first is that the IP must stay inside the company. The reason is that there are many existing contracts that it would have been complex or impossible to retain if course materials were to fully or partly belong to third parties. The second constraint was that no payment is possible for the development of the materials. Furthermore, it was clear that, based on the unclear volume expectations, in many cases attracting a crowd to invest in the development is not easy. Discussions with potential participants in a crowd made clear that none of the motivations outlined in Table 1 would work. Naturally, it was mentioned that a monetary reward covering the development costs would be an option, but this would have conflicted with the condition that there is no upfront money planned.

The outcome is a variation of existing sourcing ideas which solves the above topics: a need for development 
is announced amongst a group of key partners (a group of five) as well as, in certain cases, to additional specialty partners with the right skills. One partner is chosen based on their expertise and details of their offer to develop. The partner will develop the content based on the needs of IBM curriculum development. In general, IBM retains the responsibility for the architecture of the to-be-developed materials, but this fact can be adapted if required. Once the project is completed, the IP is transferred to IBM. Each time the materials are used, the developing partner receives a so-called 'content fee' which is negotiated upfront. During the time of the contract, the partner is responsible for the support of the course materials.

\section{Discussion and Conclusion}

\section{Categorisation}

Taking the small amount of literature into consideration (3.1) and the fact that curriculum development is, in some organisations, closely linked to development, the categorisations shown in Table 2 are a good starting point and better than designing categories from scratch.

The key difference of their work to that of IBM is straightforward: none of the four categories introduced includes a continuous payment as done by IBM. Furthermore, the motivational aspect is a key criterion that differentiates the four approaches and plays a significant overall role in their whole work.

Summarising the findings, it can be stated that the currently researched approach adds a new idea to solve the question of how to fund the contribution in a crowd. It enhances the ideas that were introduced by West and Gallagher (2006). Table 3 enhances Table 2 by adding a row with the new approach from IBM.

\begin{tabular}{llll}
\hline $\begin{array}{l}\text { Development } \\
\text { Strategy }\end{array}$ & $\begin{array}{l}\text { Maximising returns } \\
\text { of internal } \\
\text { innovation }\end{array}$ & $\begin{array}{l}\text { Role of external } \\
\text { innovation }\end{array}$ & $\begin{array}{l}\text { Motivation external } \\
\text { innovation }\end{array}$ \\
\hline $\begin{array}{l}\text { Pooled R\&D product } \\
\text { development }\end{array}$ & $\begin{array}{l}\text { Participants jointly } \\
\text { contribute to shared } \\
\text { effort }\end{array}$ & $\begin{array}{l}\text { Pooled contributions } \\
\text { available to all }\end{array}$ & $\begin{array}{l}\text { Ongoing institutions } \\
\text { establish legitimacy } \\
\text { and continuity }\end{array}$ \\
Spinouts & $\begin{array}{l}\text { Seed non- } \\
\text { commercial } \\
\text { technology to } \\
\text { support other goals }\end{array}$ & $\begin{array}{l}\text { Supplants internal } \\
\text { innovation as basis } \\
\text { of ongoing } \\
\text { innovation }\end{array}$ & $\begin{array}{l}\text { Free access to } \\
\text { valuable technology }\end{array}$ \\
Selling complements & $\begin{array}{l}\text { Target highest value } \\
\text { part of whole } \\
\text { product solution }\end{array}$ & $\begin{array}{l}\text { External components } \\
\text { provide basis for } \\
\text { internal development }\end{array}$ & $\begin{array}{l}\text { Firms coordinate } \\
\text { ongoing supply of } \\
\text { components }\end{array}$ \\
$\begin{array}{l}\text { Donated } \\
\text { complements }\end{array}$ & $\begin{array}{l}\text { Provide an } \\
\text { extensible platform } \\
\text { for external } \\
\text { contributors }\end{array}$ & $\begin{array}{l}\text { Adding variety and } \\
\text { novelty to } \\
\text { established products }\end{array}$ & $\begin{array}{l}\text { Recognition and } \\
\text { other non-monetary } \\
\text { rewards }\end{array}$ \\
\hline $\begin{array}{l}\text { Keep architecture in } \\
\text { growdsourcing with } \\
\text { payment }\end{array}$ & $\begin{array}{l}\text { Contributing product } \\
\text { and curriculum } \\
\text { development } \\
\text { experience and } \\
\text { innovation }\end{array}$ & $\begin{array}{l}\text { Pay-per-use back to } \\
\text { developing } \\
\text { organisation }\end{array}$ \\
\hline
\end{tabular}

Table 3: Open source curriculum development strategies as solutions to open innovation challenges (West \& Gallagher, 2006).

\section{Challenges}

The biggest challenge is the needed prediction of volumes.
The SaaS vendor needs to be able to predict the expected volume. From a high-level point of view, this seems to be a simple and straightforward step, but, during the first usages in IBM, this was difficult. In general, this should not be an issue, as product forecast should automatically influence the education forecast.

Internally, the forecast could still create additional challenges. On the one hand, a too low forecast will create the challenge of the crowdsourcing project not being accepted by the developing partners. On the other hand, the forecast cannot get artificially increased. The only other solution would be to use another funding approach, for example, a direct investment into those projects where the forecast is not high enough.

This leads to an interesting suggestion for general crowdsourcing in curriculum development. There are, in general, two different projects where the crowdsourced curriculum development can work. Either there is a high enough volume expectation, or, alternatively, a developing company is sufficiently interested to accept the risk of a possible loss.

We return to the recommendations from Haag et al. (2011) and van Delden (2014) to go with a small number of developing partners who are knowledgeable in the area of development. The more projects each partner gets, the greater is also the probability of investment into those projects that have a risk of not being profitable. Thus, a smaller group should be more viable in the long term. But this statement also needs further research.

\section{Further Research}

Additional basic research is needed similar to this work in investigating and categorising new approaches from the industry. The result could be a foundational collection of ideas enhancing Table 3, making it easier for organisations to re-use and build on the existing experience instead of investing in the same experience already undertaken by others.

A second field of future research could be studies moving towards the next level in the Christensen and Carlile (2009) model by using, for example, interviews after a certain experience was designed with the current approach. This could result in more details around the advantages or disadvantages and move the study into a real model.

Quantitative research around the current study could also be interesting, likely resulting in data to judge on profitability and additional key performance indicators in comparison to other existing outsourcing options.

Last, but not least, more work around the transitioning of the first four rows from the West and Gallagher (2006) Table into curriculum development needs to be done. Interviews in curriculum development organisations could be a powerful means to verify that the transition makes sense and, potentially, even add additional categories. 


\section{References}

Chesbrough, H. W. (2007). Why companies should have open business models. MIT Sloan Management Review, 48(2), 2228.

Christensen, C. M., \& Carlile, P. R. (2009). Course research: Using the case method to build and teach management theory. Academy of Management Learning \& Education, 8(2), 240-251.

Croft, L. (2018). Digital transformation is an ongoing process. Retrieved from https://www.cmswire.com/digital-workplace/ digital-transformation-is-an-ongoing-process/

Google Trends. (2019). Crowd. Retrieved from https://trends. google.com/trends/explore?date $=$ all\&geo $=U S \& q=$ crowd

Haag, S., Frey, K., \& Lüthje, C. (2011). Whom should firms attract to open innovation platforms? The role of knowledge diversity and motivation. Long Range Planning, 44(5-6), 397420. https://doi.org/10.1016/j.Irp.2011.09.006

Huizingh, E. K. R. E. (2011). Technovation open innovation: State of the art and future perspectives. Technovation, 31(1), 2-9. https://doi.org/10.1016/j.technovation.2010.10.002

Kozinets, R. V, Hemetsberger, A., \& Schau, H. J. (2008). The wisdom of consumer crowds collective innovation in the age of networked marketing. Journal of Macromarketing, 28(4), 339-354.

Lamb, A. (2016). Crowdsourcing and the school library, part 2: Connections across the curriculum. Teacher Librarian, 44(2), 56-60.

Lang, M., Bharadwaj, N., \& Di, C. A. (2016). How crowdsourcing improves prediction of market-oriented outcomes. Journal of Business Research, 69(10), 4168-4176. https://doi. org/10.1016/j.jbusres.2016.03.020

Leaser, D. (2015). The talent gap: If it is real, what can you do? Retrieved from https://www.ibm.com/blogs/ibm-training/ the-talent-gap-if-it-is-real-what-can-you-do/

McKinsey \& Co. (2008). Interop: SaaS is a key driver behind upswing in innovation; Mckinsey \& Company's Abhijit Dubey said software as a service is becoming mainstream within the IT industry, particularly among small and midsize companies. Retrieved from http://go.galegroup.com/ps/i.d?p=EAIM\&u $=$ napier\&id $=$ GALE $\% 7 C A 178430058 \& v=2.1 \& i t=r \& s i d=E A I$ M\&asid $=\mathrm{a} 04070 \mathrm{c5}$

Paulin, D., \& Haythornthwaite, C. (2016). Crowdsourcing the curriculum: Redefining e-learning practices through peergenerated approaches. The Information Society, 32(2), 130 142. https://doi.org/10.1080/01972243.2016.1130501

Peisl, T., Selen, W., \& Raeside, R. (2014). Predictive crowding and disruptive innovation: How to effectively leverage crowd intelligence. Munich, Germany: Innosabi Publishing.

Pisano, G. (2015). You need an innovation strategy. Harvard Business Review, 316(June), 1-15.

Rosenkopf, L., \& Nerkar, A. (2001). Beyond local search: Boundary-spanning, exploration, and impact in the optical disk industry. Strategic Management Journal, 22(4), 287-306.

TSIA. (2019). Technology Services Industry Association. Retrieved from https://www.tsia.com/

van Delden, C. (2014). Crowdsourced innovation: Revolutionizing open innovation with crowdsourcing: Insights and best practices. Munich, Germany: Innosabi Publishing.

West, J., \& Gallagher, S. (2006). Challenges of open innovation: The paradox of firm investment in open-source software. R\&D Management, 36(3), 319-331.

White-Farnham, J., \& Gardner, C. C. (2014). Crowdsourcing the curriculum: Information literacy instruction in first-year writing. Reference Services Review, 42(2), 277-292. https:// doi.org/10.1108/RSR-09-2013-0046

Yin, R. K. (2009). Case study research: Design and methods (4th ed.). Los Angeles, CA: Sage.

Zheng, Y., \& Dawson, J. (2017). Innovative crowdsourcing mobile app for curriculum design: Specification for a prototype mobile application. 2016 IEEE Symposium on Service-Oriented System Engineering (SOSE), 180-186. https://doi.org/10.1109/SOSE.2016.38

Copyright: @ 2020 Alexander Ziegler. This is an open-access article distributed under the terms of the Creative Commons Attribution License (CC BY). The use, distribution or reproduction in other forums is permitted, provided the original author(s) and the copyright owner(s) are credited and that the original publication in this journal is cited, in accordance with accepted academic practice. No use, distribution or reproduction is permitted which does not comply with these terms. 